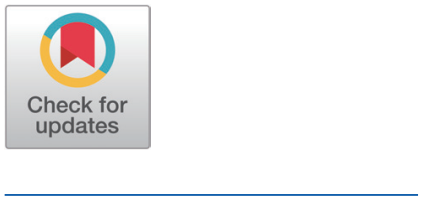

Received: Jul 21, 2021

Revised: Aug 16, 2021

Accepted: Aug 20, 2021

*Corresponding author

$\mathrm{Na}$ Yeon Kim

Asia Pacific Ruminant Institute, Icheon

17385 , Korea.

Tel: +82-31-632-2865

E-mail: narziss924@hanmail.net

Copyright (C) 2021 Korean Society of Animal Sciences and Technology. This is an Open Access article distributed under the terms of the Creative Commons Attribution

Non-Commercial License (http:// creativecommons.org/licenses/by$\mathrm{nc} / 4.0 /$ ) which permits unrestricted non-commercial use, distribution, and reproduction in any medium, provided the original work is properly cited.

ORCID

Farhad Ahmadi

https://orcid.org/0000-0002-8760-053X Seongjin Kim

https://orcid.org/0000-0002-5490-6268

Deok Hwangbo

https://orcid.org/0000-0002-4486-2222

Yongik Oh

https://orcid.org/0000-0002-1695-4808

Jisu Yu

https://orcid.org/0000-0001-7608-2573

Jisun Bae

https://orcid.org/0000-0001-9871-3209

$\mathrm{Na}$ Yeon Kim

https://orcid.org/0000-0002-2016-9714

Competing interests

No potential conflict of interest relevant to this article was reported.

Funding sources

Not applicable.

\section{Performance of Hanwoo calves fed a commercial colostrum replacer versus natural bovine colostrum}

\author{
Farhad Ahmadi ${ }^{1}$, Seongjin $\mathrm{Kim}^{2}$, Deok Hwangbo², Yongik $\mathrm{Oh}^{3}$, Jisu $\mathrm{Yu}^{3}$, \\ Jisun $\mathrm{Bae}^{2}$ and $\mathrm{Na}$ Yeon $\mathrm{Kim}^{2 *}$ \\ ${ }^{1}$ Division of Food Biosciences, College of Medical Life Sciences, Konkuk University, Chungju 27478, Korea \\ ${ }^{2}$ Asia Pacific Ruminant Institute, Icheon 17385, Korea \\ ${ }^{3}$ Icheon-si Agricultural Technology Center, Icheon 17379, Korea
}

\section{Abstract}

Supplying a sufficient amount of high-quality colostrum is a prevailing challenge in Hanwoo calf production systems. This study aimed to describe the efficiency of a lacteal-derived colostrum replacer versus natural bovine colostrum (from Holstein) fed to Hanwoo calves. Forty newborn Hanwoo calves ( 25 males and 15 females; $30.7 \pm 3.15 \mathrm{~kg}$ body weight [mean \pm standard deviation]) were blocked by sex and birth weight and fed either natural colostrum or a commercial colostrum replacer. Calves displayed a narrow difference in the evolution of body weight and structural body dimensions when they received a commercial versus natural colostrum. Minor differences existed in the starter and total dry matter consumption between calves fed natural or commercial colostrum. Although the colostrum source had no significant effects on days to first diarrhea (average of 7.6 days; $p=0.17$ ), the duration of diarrhea was longer in natural colostrum-fed calves ( 3.2 vs. 4.5 days; $p=0.04$ ). Consumption of natural colostrum resulted in greater mean serum immunoglobulin $\mathrm{G}(\mathrm{lgG})$ on day 2 (14.7 vs. $10.8 \pm$ $0.92 \mathrm{mg} / \mathrm{mL}$ ) and day 7 (8.21 vs. $5.12 \pm 0.82 \mathrm{mg} / \mathrm{mL}$ ) of calf life, resulting in a greater proportion of commercial colostrum-fed calves (50\% vs. $15 \%$; day 2$)$ to experience failure of passive transfer of immunity (serum $\mathrm{lgG}<$ cutoff point of $10 \mathrm{mg} / \mathrm{mL}$ ). Overall, growth rate, body frame development, and incidence of diarrheal disease were not different in both groups. These results suggested that the colostrum replacer product tested in this study could be an alternative to natural colostrum derived from Holstein cow in securing calf growth and health in Hanwoo calf-rearing operations.

Keywords: Colostrum replacer, Diarrhea, Hanwoo calf, Performance

\section{INTRODUCTION}

Colostrum plays a crucial role in transferring maternal immunoglobulins to neonatal calves, as cows are incapable of uterine transfer of immunoglobulins to their calves [1-4]. Consumption of a sufficient quantity of high-quality colostrum during the initial hours of calf life is critical in securing an adequate transfer of colostral immunoglobulins into circulation, contributing to the effective establishment of passive immunization and thus the minimization of morbidity and mortality in neonatal calf [5-7]. 
Acknowledgements Not applicable.

Availability of data and material Upon reasonable request, the datasets of this study can be available from the corresponding author.

\section{Authors' contributions}

Conceptualization: Ahmadi F, Kim S, Kim NY. Data curation: Kim S, Hwangbo D, Bae J, Kim NY.

Formal analysis: Ahmadi F, Kim S, Oh Y, Yu J. Methodology: Ahmadi F, Kim S, Kim NY.

Validation: Kim S, Kim NY.

Investigation: Kim S.

Writing - original draft: Ahmadi F, Kim S, Kim NY

Writing - review \& editing: Ahmadi F, Kim S, Hwangbo D, Oh Y, Yu J, Bae J, Kim NY.

Ethics approval and consent to participate This research was approved by Institutional Animal Care and Use Committee of Konkuk University, Korea (Approval no: KU17099).
Despite the vital importance of colostrum feeding, poor colostrum management, including improper collection, handling, or storage procedures, can expose neonatal calves to pathogens, impairing immunoglobulin absorption and jeopardizing calf health and productivity [8-10]. Occasionally, producers are also unable to supply a sufficient quantity of high-quality, disease-free colostrum, particularly when the transmission cycle for certain infectious pathogens, such as bovine leukosis virus or Mycoplasma bovis mastitis, must be disrupted [11-13]. Poor colostrum quality and inadequate colostrum reserves are predominantly prevalent among Hanwoo calf (Korean native breed)-rearing operations, where calves usually acquire colostrum via nursing. However, there has been a recent trend to immediately separate calves from their dam, resulting in the diminishment of morbidity rates associated with hygienic issues. Hanwoo cows are usually unable to produce a sufficient quantity of colostrum; therefore, an adequate supply of high-quality colostrum is a challenging concern when newborn calves are moved to individual boxes.

These issues have driven the industry to commercialize colostrum replacement products that would enable calf producers to have timely access to colostrum of consistent quality in adequate quantities. However, a major concern with a commercial colostrum replacer is whether the antigenspecific antibodies in the product are available in sufficient quantities and have the necessary efficiency in providing adequate defense against farm-specific pathogens $[8,14]$. There is less evidence to support the comparative effectiveness of commercial colostrum replacer products versus natural bovine colostrum on calf performance and health, particularly in native species, such as Hanwoo calf that has received little attention.

A literature review has shown conflicting findings regarding the efficacy of commercial colostrum replacers in establishing a sufficient passive immunity transfer in neonatal calves $[12,13,15]$. For example, Smith and Foster [12] reported that their tested colostrum replacer failed to pass sufficient IgG into calf serum circulation. This necessitates the prior-to-use assessment of any colostrum replacer product, particularly its ability to pass appropriate $\operatorname{Ig} G$ concentrations into calf circulation. Producers would be able to make more accurate decisions about their colostrum management program if they have access to such information. Therefore, this study aimed to compare the performance, health, and passive transfer of $\mathrm{IgG}$ in newborn Hanwoo calves fed a commercially available lacteal-derived colostrum replacer versus natural bovine colostrum.

\section{MATERIALS AND METHODS}

Experiments that involved animals were conducted in conformance with the guidelines approved by Konkuk University (approval no. KU17099). The experiment was implemented at the Asia Pacific Ruminant Institute (Icheon, Gyeonggi-do, Korea). A descriptive explanation of calf management has been published previously [16]. In brief, 40 calves were enrolled for the experiment, separated immediately at birth from their dams, and received either natural bovine colostrum (12 males and 8 females) or colostrum-based replacement product (13 males and 7 females). The colostrum replacer was a commercially available product derived from bovine colostrum (Headstart, Saskatoon Colostrum, Saskatoon, SK, Canada). In both groups, colostrum was fed through a bottle within 4 $\mathrm{h}$ of birth. A target temperature of about $41^{\circ} \mathrm{C}$ was set before colostrum feeding. The commercial

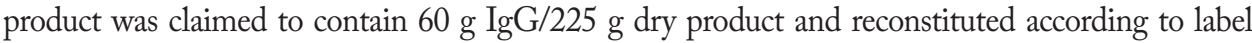
directions (225 g in $800 \mathrm{~mL}$ water). First-milking colostrum was originated from Holstein cows and collected under aseptic conditions through a vacuum milking system. Prior to colostrum collection, Holstein cows were certified to be healthy and to have received no special treatments. The collected colostrum was tested using a colostrometer, and only the high-quality colostrum with a mean $\mathrm{IgG}$ concentration of $>50 \mathrm{~g} / \mathrm{L}$ [11] was kept for the experiment. The verified colostrum 
was pasteurized $\left(60^{\circ} \mathrm{C}\right.$ for $\left.30 \mathrm{~min}\right)$ and stored frozen at $-20^{\circ} \mathrm{C}$ for experimental use. Calves were housed individually in wooden pens $(2.0 \mathrm{~m}$ long $\times 1.35 \mathrm{~m}$ wide $\times 1.2 \mathrm{~m}$ high $)$ from day 2 of birth Sawdust was used as bedding, which was replenished when required. Calves received a commercial milk replacer (150 g in $1 \mathrm{~L}$ water; Nukamel Yellow, The Dawn, Seoul, Korea) at $8 \mathrm{~L} /$ day until 30 days of age, which was gradually decreased from days 31 to 60 (weaning). The nutrient composition of milk replacer powder is shown in Table 1. Milk replacer was fed through the Calf Rail Feeding System (Foerster-Technik, Engen, Germany). Calves that displayed clinical diarrhea were treated using established farm protocols involving the administration of baytril, biodyl, and ketoprofen and an oral solution (Liquid Life-Aid, Norbrook, Newry, UK) containing glucose, glycerin, potassium dihydrogen phosphate, and sodium chloride. Calves with bloody diarrhea were also injected with Ampura-Q (Health Pharma, Dhaka, Bangladesh) according to the veterinarian's prescription.

Fecal samples in diarrhetic calves were submitted to a commercial laboratory to identify pathogenic agents (rotavirus, coronavirus, Escherichia coli K99, and Cryptosporidium parvum) using a commercial kit (Celltrix, Seongnam, Korea). Water was provided in free access in individual buckets. A commercial starter feed (DH Vital Feed, Pyeongtaek, Korea) was freely available in individual buckets from day 2 of calf life. The nutrient composition of starter feed and timothy hay was presented in Table 2. Starter feed consumption was recorded daily. Individual milk replacer consumption was recorded automatically daily through the amount of milk dispensed from the feeding system. Calf weighing was made using a scale (HFS, CAS Scale, Seoul, Korea) on a 10-day basis approximately $2 \mathrm{~h}$ after the morning feeding. Body frame dimensions, including heart girth,

Table 1. Nutrient composition of the milk replacer powder

\begin{tabular}{|c|c|}
\hline Nutrient composition & $\%$ of DM \\
\hline DM (\%) & 93.8 \\
\hline Crude protein & 24.4 \\
\hline Crude fat & 17.1 \\
\hline Crude ash & 7.52 \\
\hline Calcium & 0.79 \\
\hline Phosphorous & 0.61 \\
\hline
\end{tabular}

DM, dry matter.

Table 2. Nutrient composition of starter feeds and timothy hay

\begin{tabular}{lccc}
\hline \multirow{2}{*}{ Nutrient composition } & \multicolumn{2}{c}{ Starter feeds } & \multirow{2}{*}{ Timothy hay } \\
\cline { 2 - 3 } & Starter A & Starter B & \\
\hline DM (\%) & 91.8 & 89.9 & 90.1 \\
Crude protein (\% of DM) & 24.9 & 17.0 & 14.8 \\
Crude fiber (\% of DM) & 9.20 & 8.01 & 33.8 \\
Acid detergent fiber (\% of DM) & 10.9 & 11.0 & 37.7 \\
Neutral detergent fiber (\% of DM) & 22.0 & 22.0 & 67.1 \\
Total fat (\% of DM) & 5.90 & 3.70 & 1.13 \\
Calcium (\% of DM) & 0.90 & 0.90 & 0.18 \\
Phosphorous (\% of DM) & 0.50 & 0.50 & 0.14 \\
Total digestible nutrients (\% of DM) & 75.8 & 72.8 & - \\
\hline Timothy hay (Phleum pratense L.) was chopped to a mean particle size of 2.5 mm and added to starter A at 5\% and starter B at 10\%. \\
1)Starter A was available freely to calves from day 2 of life. Starter B was fed to calves when they could consume a minimum of \\
500 g starter A. & & & \\
DM, dry matter. & & &
\end{tabular}


body weight, body barrel, withers height, and hip height, were also measured at birth and then on a 10-day basis before the experiment ended on day 70 [17]. Blood was collected from each calf via the jugular vein for $\mathrm{IgG}$ quantification on days 2, 7, 30, and 60 before morning feeding. The $\mathrm{IgG}$ content in serum samples was quantified using a bovine IgG ELISA kit (Koma-Biotech,Seoul, Korea).

\section{Statistical analysis}

Calves enrolled in the experiment were blocked by sex and birth weight and then assigned randomly to one of two treatments in a completely randomized block design. Continuous data were subjected to a normality test through Univariate Proc in SAS (SAS Institute, Cary, NC, USA). Any data that did not follow a normal distribution pattern (starter intake, total dry matter [DM] intake, average daily gain, body weight, withers height, and hip height) was logarithmically transformed. Data were analyzed as a completely randomized design using Mixed Proc. The experimental unit was an individual calf. Data collected over time were analyzed as repeated measures. Autoregressive type 1 resulted in the smallest Akaike information criterion and was selected. Calf birth weight was included in the model as a covariate. Tukey's test was used for means separation. The difference between treatments for days to first diarrhea and days with diarrhea was identified using GENMOD Proc with a Poisson distribution [18]. The threshold level of significance was $p<0.05$.

\section{RESULTS AND DISCUSSION}

No calf death or exclusion occurred during the experiment. Both groups consumed colostrum at a similar amount of $2.40 \pm 0.75$ and $2.35 \pm 0.91 \mathrm{~L}(p=0.70)$ for commercial and natural colostrumfed calves, respectively. Failure of passive transfer of immunity $(\mathrm{IgG}<10 \mathrm{mg} / \mathrm{mL})$ and mean serum $\mathrm{IgG}$ concentration are shown in Fig. 1. On day 2 of calf life, greater circulating $\operatorname{IgG}$ was quantified in calves fed natural colostrum versus colostrum replacer $(10.8$ vs. $14.7 \pm 0.92 \mathrm{mg} / \mathrm{mL}$; $p<0.01$ ). Failure to transfer adequate $\operatorname{IgG}$ concentration into calf circulation was clearly visible in commercial colostrum-fed calves, with 10 of 20 calves with a blood IgG concentration of $<10 \mathrm{mg} /$ $\mathrm{mL}$. In contrast, 3 (of 20) calves failed to absorb an adequate amount of $\operatorname{IgG}$ when they received natural colostrum, suggesting the superiority of natural colostrum in securing a successful passive immunization [3,11]. A colostrum replacer is described as a successful product if it can raise serum IgG levels above $10 \mathrm{mg} / \mathrm{mL}$ within the first 2 days of calf life [19]. Smith and Foster [12] indicated that natural colostrum versus commercial colostrum led to higher serum IgG levels, supporting the finding that natural colostrum feeding transferred more IgG into calf serum in the early days of calf life. Garry et al. [20] also compared the efficacy of three commercially available colostrum replacer products and reported greater serum IgG levels in natural versus colostrum replacer-fed calves. The success of maintaining an adequate transfer of immunity could not be predicted by the $\operatorname{Ig} G$ level in the colostrum product because several factors, such as $\mathrm{IgG}$ origin and the quantity and type of nonIgG protein, could affect the efficiency of IgG absorption [12,21,22].

The evolution of mean starter intake and total DM intake (for 70 days) in Hanwoo calves fed commercial colostrum versus natural colostrum is shown in Fig. 2. Calves displayed no difference in their starter and total DM intake (starter feed + milk replacer DM) when their colostrum source differed. Likewise, da Silva et al. [23] compared the efficacy of bovine-derived colostrum replacer to maternal colostrum and found a narrow effect on calf starter consumption.

Body weight and daily gains in body weight (from 1 to 70 days of age) in Hanwoo calves fed commercial colostrum versus natural colostrum are shown in Fig. 3. In general, the mean birth weight $(30.7 \pm 3.15 \mathrm{~kg})$ and daily body gains in this experiment were comparable to those reported 
A

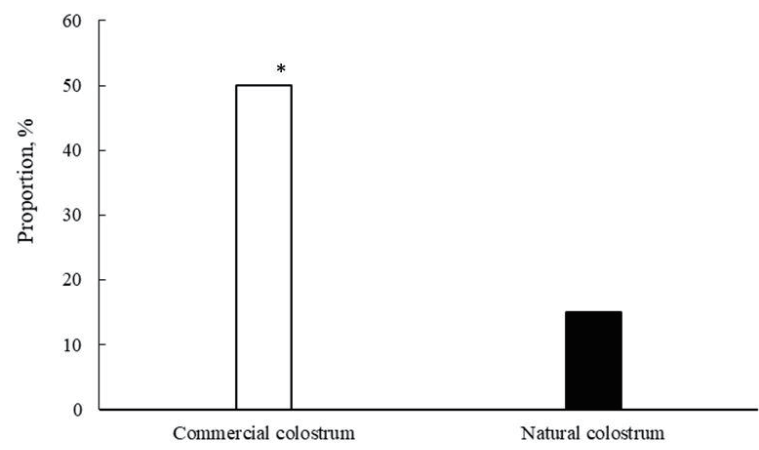

B

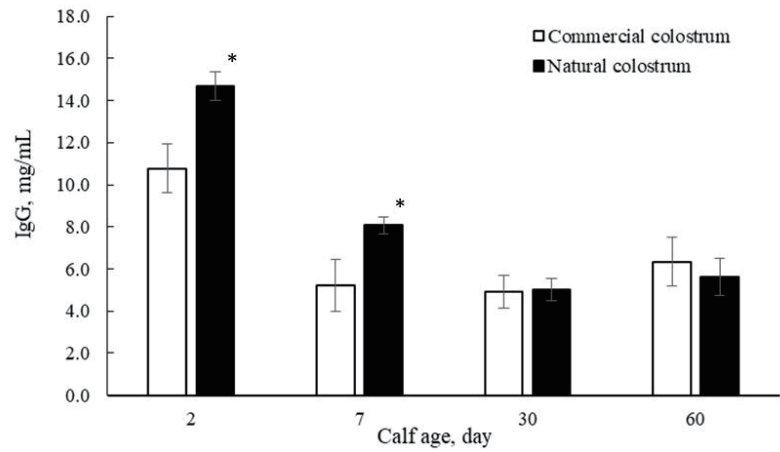

Fig. 1. Failure of colostral immunoglobulin $G$ transfer (lgG $<10 \mathrm{mg} / \mathrm{mL}$; day 2 of calf life) (A) and mean \pm SE blood IgG concentrations at 2, 7, 30, and 60 days of life (B) in Hanwoo calves fed commercial colostrum (white columns) versus natural colostrum (black columns). Means with an asterisk at each time point differ $(p<0.05)$.

A

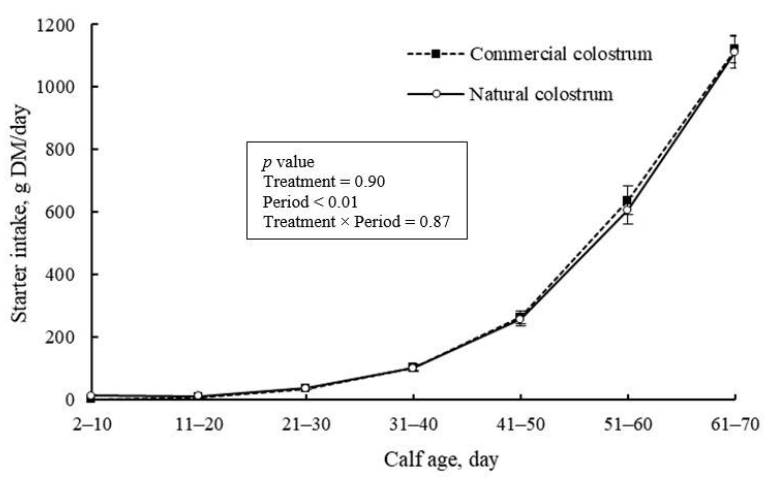

B

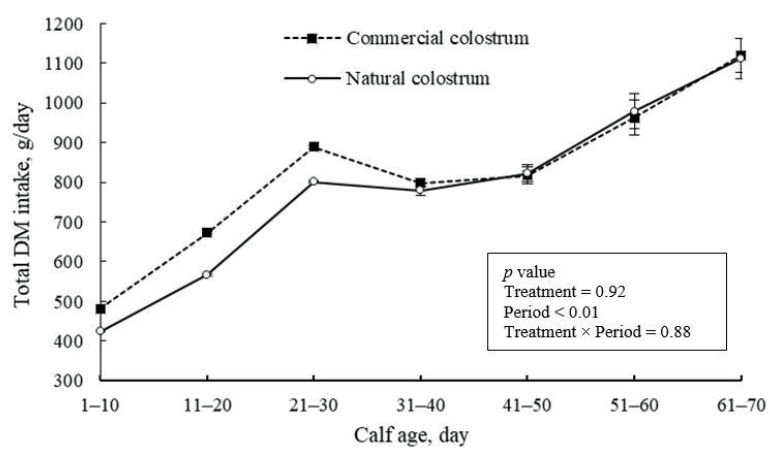

Fig. 2. Evolution of mean $\pm S E$ starter intake $(A)$ and total $D M$ intake (B; milk replacer $D M+$ starter $D M)$ in Hanwoo calves fed commercial colostrum ( $₫$ ) versus natural colostrum (०). DM, dry matter. 
A

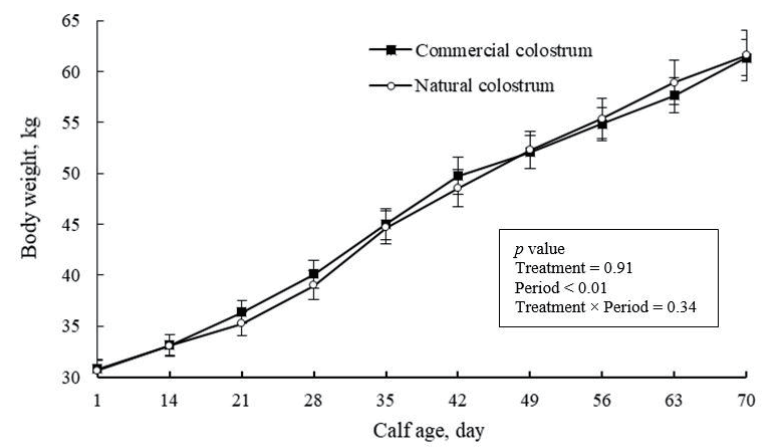

B

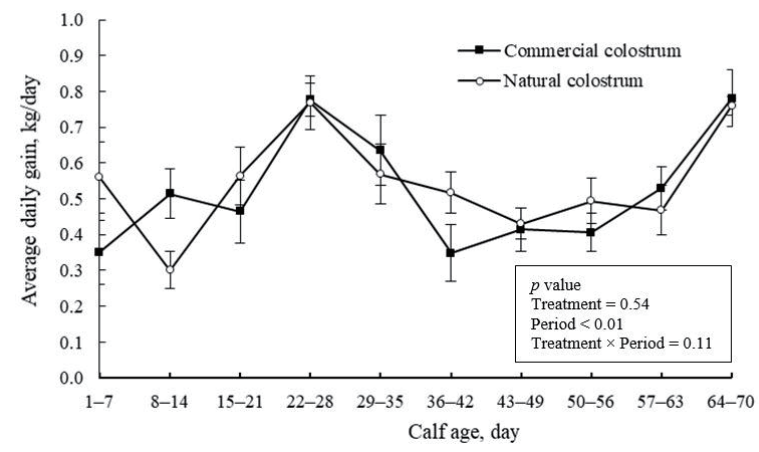

Fig. 3. Evolution of mean \pm SE body weight $(A)$ and average daily gain $(B)$ in Hanwoo calves fed commercial colostrum ( $\square$ ) versus natural colostrum (O).

previously with Hanwoo calves $[16,24,25]$. Body weight increased with calf age, with only a small variation observed between calves fed different colostrum sources. Similarly, Jones et al. [14] found no difference in growth rate (from birth to 5 weeks) between calves fed natural colostrum or plasma-derived colostrum replacer. Contrary to these findings, Priestley et al. [26] and Lago et al. [13] reported heavier weaning weight and greater daily gain in calves fed maternal colostrum versus commercial colostrum replacer. Several studies have found a negative relationship between passive transfer failure and calf growth rate [27-29]. However, such an effect was not identified in this experiment. Despite the higher prevalence of failure of passive transfer in commercial colostrum-fed calves, they grew at a rate similar to those fed natural colostrum. Furman-Fratczak et al. [30] found no association between serum IgG and calf growth during the first 6 months of life, supporting the findings of this study. Godden et al. [31] argued that despite the recommended cutoff point in several reports (serum $\mathrm{IgG}>10 \mathrm{mg} / \mathrm{mL}$ ), the lower or higher values might be considered the optimum serum IgG concentration for individual farms to secure efficient calf performance.

The body dimensions are shown in Figs. 4 and 5. Body frame development increased with developing calf age. However, the colostrum source had no significant effects on these measures, as expected, as it also had no effects on calf solid intake and daily growth rate. Consumption of a sufficient volume of high-quality colostrum triggers anabolic metabolism at the tissue level, promoting postnatal body growth and organ development $[4,9]$. The lack of significant differences in structural growth parameters among calves suggests the successful efficacy of commercial colostrum replacer in promoting calf growth and development. In support, da Silva et al. [23] and Jones et al. [14] also identified minor differences in heart girth, hip height, and withers height of Holstein calf fed a lacteal-derived colostrum replacer versus maternal colostrum.

The onset and duration of diarrhea in calves fed commercial versus natural colostrum are shown in Fig. 6. Although colostrum source had no significant effects on days to the first occurrence of 
A

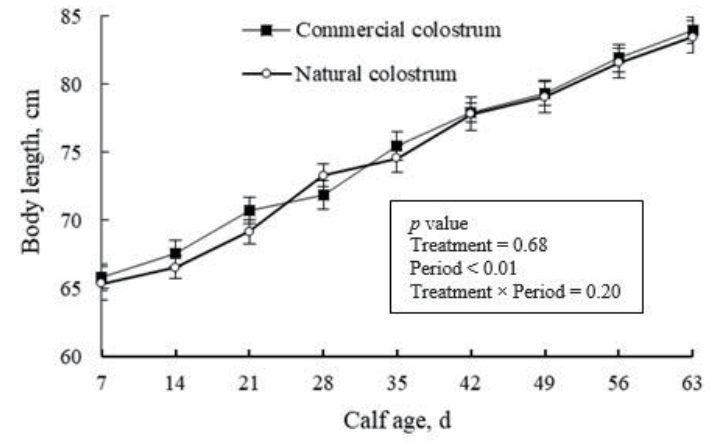

B

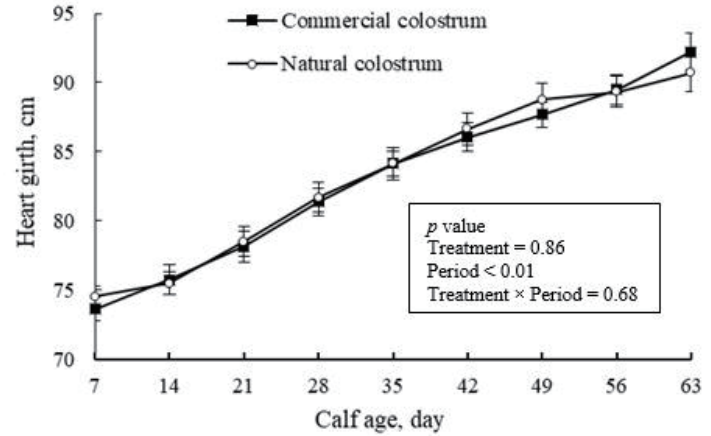

C

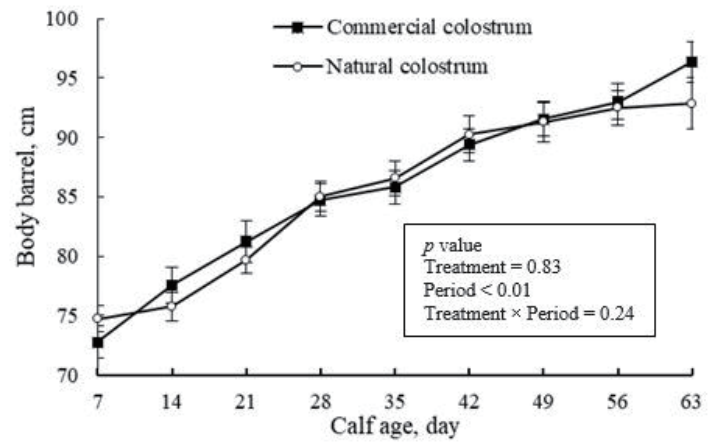

Fig. 4. Mean \pm SE body length (A), heart girth (B), and body barrel (C) in Hanwoo calves fed commercial colostrum ( $(\mathbf{)})$ versus natural colostrum (O).

diarrhea (average, $7.6 \pm 3.30$ days; $p=0.17$ ), the number of days with diarrhea was greater in calves fed natural colostrum ( 3.2 vs. $4.5 \pm 2.57$ days; $p=0.04$ ). Diarrhea is the main cause of mortality and morbidity in calf-rearing operations worldwide, and it is caused primarily by viral (rotavirus or coronavirus), bacterial, or parasitic pathogens [32]. Diarrheic calves in this experiment were often diagnosed with rotavirus infection. Typically, calves are highly susceptible to rotavirus diarrhea during their first few weeks of life; this is why passive immunity via colostrum is an important defensive strategy for prevention of rotavirus infection and disease [33-35]. Several studies have identified that the transfer of serum $\operatorname{IgG}$ antibodies into the intestine provides a complementary role in protection against rotavirus diarrhea in neonatal calves $[33,36]$. The shorter duration of diarrhea in commercial colostrum-fed calves might provide evidence about the efficacy of this product in protecting Hanwoo calves against rotavirus diarrhea. Lago et al. [13] reported that calves fed commercial colostrum replacer tended to exhibit a lower incidence of diarrhea but a higher number of days with diarrhea than those fed maternal colostrum. Consumption of highquality colostrum during the first days of calf life aids in establishing adequate passive immunity, 
A

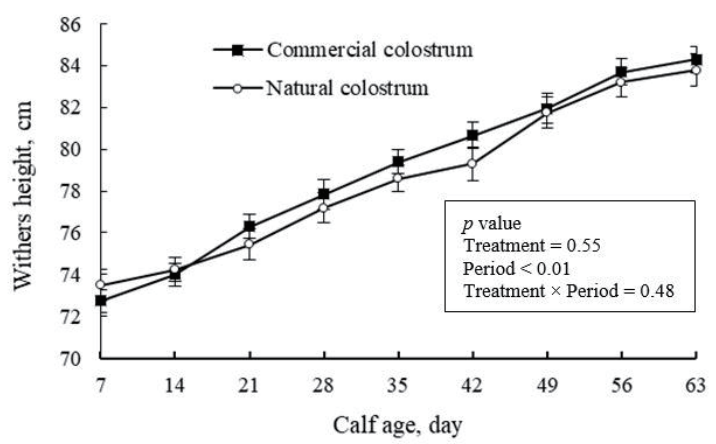

B

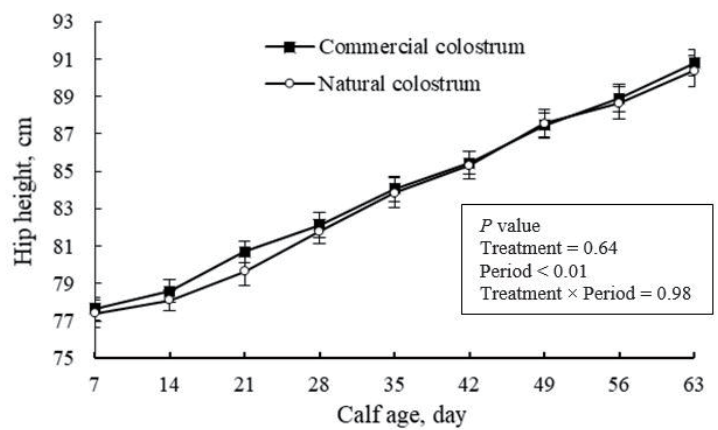

Fig. 5. Mean \pm SE withers height (A) and hip height (B) in Hanwoo calves fed commercial colostrum ( $\square$ ) versus natural colostrum (०).

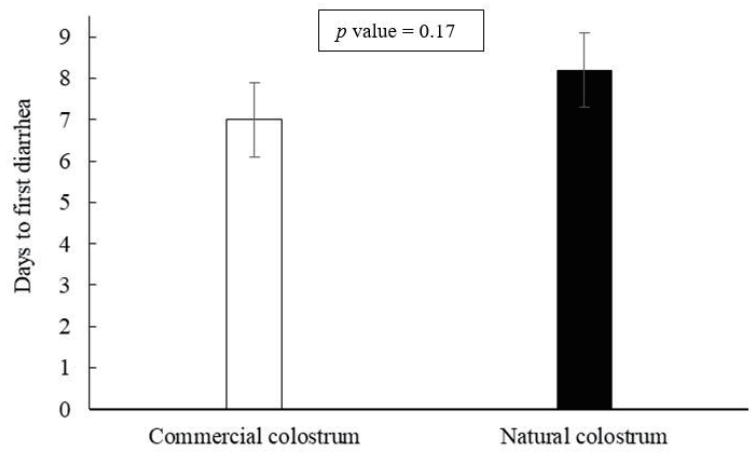

B

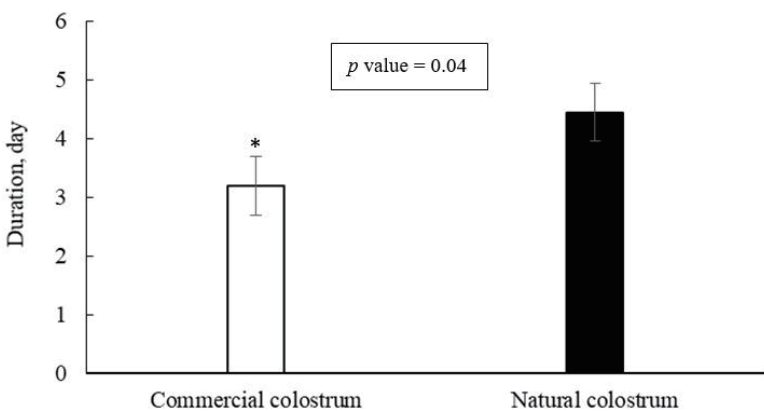

Fig. 6. Time to reach first diarrhea (A) and days with diarrhea (B) in Hanwoo calves fed commercial colostrum (white column) versus natural colostrum (black column). Means with an asterisk differ $(p<0.05)$. 
which is especially important in minimizing the prevalence of extreme neonatal calf diarrhea, the leading cause of neonatal calf death [9,37]. Colostrum immunoglobulins facilitate the development of local neonatal immunity against a variety of pathogens involved in diarrheal disease in calves $[38,39]$. This might provide additional evidence about the efficacy of the colostrum replacer product in transferring the passive immunity, as the colostrum source had a small effect on the prevalence of diarrhea in Hanwoo calves. Contrary to our finding, Priestley et al. [26] reported that maternal colostrum was superior to a plasma-derived colostrum replacer in diminishing the prevalence of calf diarrhea. Immunoglobulins derived from blood plasma are less effective than lacteal-derived colostrum replacers in preventing the prevalence of neonatal calf diarrhea. An abundance of hormones, growth factors, and cell-modulating factors in lacteal-originated colostrum can contribute to calf gut health and development that is associated with a lower rate of diarrhea incidence in neonates $[9,40,41]$.

\section{CONCLUSION}

Although feeding commercial colostrum increased the risk of failure to transfer adequate immunoglobulins into calf circulation, calves consuming commercial or natural colostrum exhibited no significant differences in their daily gains in body weight and body frame evolution and solid feed intake. Despite the lack of significant effects on the onset of diarrhea, the duration of diarrhea was longer in natural colostrum-fed calves. These findings provide evidence that the commercial colostrum replacer evaluated in this study might be seen as an alternative to natural colostrum in Hanwoo calf-rearing operations, where the timely supply of high-quality colostrum is still a challenge. Additional experiments are needed to identify potential differences in long-term productivity and health of Hanwoo calves fed a colostrum replacer product.

\section{REFERENCES}

1. Quigley JD III, Drewry JJ. Nutrient and immunity transfer from cow to calf pre- and postcalving. J Dairy Sci. 1998;81:2779-90. https://doi.org/10.3168/jds.S0022-0302(98)75836-9

2. Barrington GM, Parish SM. Bovine neonatal immunology. Vet Clin North Am Food Anim Pract. 2001;17:463-76. https://doi.org/10.1016/S0749-0720(15)30001-3

3. Godden S. Colostrum management for dairy calves. Vet Clin North Am Food Anim Pract. 2008;24:19-39. https://doi.org/10.1016/j.cvfa.2007.10.005

4. Liermann W, Schäff CT, Gruse J, Derno M, Weitzel JM, Kanitz E, et al. Effects of colostrum instead of formula feeding for the first 2 days postnatum on whole-body energy metabolism and its endocrine control in neonatal calves. J Dairy Sci. 2020;103:3577-98. https://doi. org/10.3168/jds.2019-17708

5. Conneely M, Berry DP, Murphy JP, Lorenz I, Doherty ML, Kennedy E. Effect of feeding colostrum at different volumes and subsequent number of transition milk feeds on the serum immunoglobulin G concentration and health status of dairy calves. J Dairy Sci. 2014;97:69917000. https://doi.org/10.3168/jds.2013-7494

6. Armengol R, Fraile L. Colostrum and milk pasteurization improve health status and decrease mortality in neonatal calves receiving appropriate colostrum ingestion. J Dairy Sci. 2016;99:4718-25. https://doi.org/10.3168/jds.2015-10728

7. Heinrichs AJ, Jones CM, Erickson PS, Chester-Jones H, Anderson JL. Symposium review: colostrum management and calf nutrition for profitable and sustainable dairy farms. J Dairy Sci. 2020;103:5694-9. https://doi.org/10.3168/jds.2019-17408 
8. Swan H, Godden S, Bey R, Wells S, Fetrow J, Chester-Jones H. Passive transfer of immunoglobulin $\mathrm{G}$ and preweaning health in Holstein calves fed a commercial colostrum replacer. J Dairy Sci. 2007;90:3857-66. https://doi.org/10.3168/jds.2007-0152

9. Hammon HM, Liermann W, Frieten D, Koch C. Review: importance of colostrum supply and milk feeding intensity on gastrointestinal and systemic development in calves. Animal. 2020;14:s133-43. https://doi.org/10.1017/S1751731119003148

10. Godden SM, Lombard JE, Woolums AR. Colostrum management for dairy calves. Vet Clin North Am Food Anim Pract. 2019;35:535-56. https://doi.org/10.1016/j.cvfa.2019.07.005

11. McGuirk SM, Collins M. Managing the production, storage, and delivery of colostrum. Vet Clin North Am Food Anim Pract. 2004;20:593-603. https://doi.org/10.1016/j.cvfa.2004.06.005

12. Smith GW, Foster DM. Short communication: absorption of protein and immunoglobulin G in calves fed a colostrum replacer. J Dairy Sci. 2007;90:2905-8. https://doi.org/10.3168/ jds.2006-682

13. Lago A, Socha M, Geiger A, Cook D, Silva-del-Río N, Blanc C, et al. Efficacy of colostrum replacer versus maternal colostrum on immunological status, health, and growth of preweaned dairy calves.J Dairy Sci. 2018;101:1344-54. https://doi.org/10.3168/jds.2017-13032

14. Jones CM, James RE, Quigley JD III, McGilliard ML. Influence of pooled colostrum or colostrum replacement on IgG and evaluation of animal plasma in milk replacer. J Dairy Sci. 2004;87:1806-14. https://doi.org/10.3168/jds.S0022-0302(04)73337-8

15. Foster DM, Smith GW, Sanner TR, Busso GV. Serum IgG and total protein concentrations in dairy calves fed two colostrum replacement products. J Am Vet Med Assoc. 2006;229:12825. https://doi.org/10.2460/javma.229.8.1282

16. Peng DQ, Jo YH, Kim SJ, Kim NY, Nejad JG, Lee HG. Oral vitamin A supplementation during neonatal stage enhances growth, pre-adipocyte and muscle development in Korean native calves. Anim Feed Sci Technol. 2020;268:114609. https://doi.org/10.1016/j.anifeedsci.2020.114609

17. Khan MA, Lee HJ, Lee WS, Kim HS, Ki KS, Hur TY, et al. Structural growth, rumen development, and metabolic and immune responses of Holstein male calves fed milk through stepdown and conventional methods. J Dairy Sci. 2007;90:3376-87. https://doi.org/10.3168/ jds.2007-0104

18. Abbaslou Y, Mahjoubi E, Ahmadi F, Farokhzad MR, Zahmatkesh D, Yazdi MH, et al. Short communication: performance of Holstein calves fed high-solid milk with or without nucleotide. J Dairy Sci. 2020;103:11490-5. https://doi.org/10.3168/jds.2020-18977

19. Quigley JD, Strohbehn RE, Kost CJ, O'Brien MM. Formulation of colostrum supplements, colostrum replacers and acquisition of passive immunity in neonatal calves. J Dairy Sci. 2001;84:2059-65. https://doi.org/10.3168/jds.S0022-0302(01)74650-4

20. Garry FB, Adams R, Cattell MB, Dinsmore RP. Comparison of passive immunoglobulin transfer to dairy calves fed colostrum or commercially available colostral-supplement products. J Am Vet Med Assoc. 1996;208:107-10.

21. Arthington JD, Cattell MB, Quigley JD III. Effect of dietary IgG source (colostrum, serum, or milk-derived supplement) on the efficiency of $\mathrm{Ig}$ absorption in newborn Holstein calves. J Dairy Sci. 2000;83:1463-7. https://doi.org/10.3168/jds.S0022-0302(00)75018-1

22. Davenport DF, Quigley JD III, Martin JE, Holt JA, Arthington JD. Addition of casein or whey protein to colostrum or a colostrum supplement product on absorption of IgG in neonatal calves. J Dairy Sci. 2000;83:2813-9. https://doi.org/10.3168/jds.S0022-0302(00)75180-0

23. da Silva AP, de Toledo AF, Cezar AM, Coelho MG, Virginio GF Júnior, Poczynek M, et al. 
Passive transfer and neonatal health in dairy calves receiving maternal colostrum and/or a colostrum replacer. Livest Sci. 2020;240:104158. https://doi.org/10.1016/j.livsci.2020.104158

24. Peng DQ, Kim SJ, Lee HG. Metabolomics analyses to characterize metabolic alterations in Korean native calves by oral vitamin A supplementation. Sci Rep. 2020;10:8092. https://doi. org/10.1038/s41598-020-65023-y

25. Jo YH, Peng DQ, Kim WS, Kim SJ, Kim NY, Kim SH, et al. The effects of vitamin A supplementation during late-stage pregnancy on longissimus dorsi muscle tissue development, birth traits, and growth performance in postnatal Korean native calves. Asian-Australas J Anim Sci. 2020;33:742-52. https://doi.org/10.5713/ajas.19.0413

26. Priestley D, Bittar JH, Ibarbia L, Risco CA, Galvão KN. Effect of feeding maternal colostrum or plasma-derived or colostrum-derived colostrum replacer on passive transfer of immunity, health, and performance of preweaning heifer calves.J Dairy Sci. 2013;96:3247-56. https://doi. org/10.3168/jds.2012-6339

27. Robison JD, Stott GH, DeNise SK. Effects of passive immunity on growth and survival in the dairy heifer.J Dairy Sci. 1988;71:1283-7. https://doi.org/10.3168/jds.S0022-0302(88)79684-8

28. Mee JF, O'Farrell KJ, Reitsma P, Mehra R. Effect of a whey protein concentrate used as a colostrum substitute or supplement on calf immunity, weight gain, and health. J Dairy Sci. 1996;79:886-94. https://doi.org/10.3168/jds.S0022-0302(96)76437-8

29. Donovan GA, Dohoo IR, Montgomery DM, Bennett FL. Associations between passive immunity and morbidity and mortality in dairy heifers in Florida, USA. Prev Vet Med. 1998;34:31-46. https://doi.org/10.1016/S0167-5877(97)00060-3

30. Furman-Fratczak K, Rzasa A, Stefaniak T. The influence of colostral immunoglobulin concentration in heifer calves' serum on their health and growth. J Dairy Sci. 2011;94:5536-43. https://doi.org/10.3168/jds.2010-3253

31. Godden SM, Haines DM, Hagman D. Improving passive transfer of immunoglobulins in calves. I: dose effect of feeding a commercial colostrum replacer. J Dairy Sci. 2009;92:1750-7. https://doi.org/10.3168/jds.2008-1846

32. Berchtold J. Treatment of calf diarrhea: intravenous fluid therapy. Vet Clin North Am Food Anim Pract. 2009;25:73-99. https://doi.org/10.1016/j.cvfa.2008.10.001

33. Saif LJ, Weilnau P, Miller K, Stitzlein L. Isotypes of intestinal and systemic antibodies in colostrum-fed and colostrum-deprived calves challenged with rotavirus. Adv Exp Med Biol. 1987;216B:1815-23.

34. Bridger JC. A definition of bovine rotavirus virulence. J Gen Virol. 1994;75:2807-12. https:// doi.org/10.1099/0022-1317-75-10-2807

35. Vega C, Bok M, Chacana P, Saif L, Fernandez F, Parreño V. Egg yolk IgY: protection against rotavirus induced diarrhea and modulatory effect on the systemic and mucosal antibody responses in newborn calves. Vet Immunol Immunopathol. 2011;142:156-69. https://doi. org/10.1016/j.vetimm.2011.05.003

36. Besser TE, McGuire TC, Gay CC, Pritchett LC. Transfer of functional immunoglobulin G ( $\mathrm{IgG}$ ) antibody into the gastrointestinal tract accounts for $\mathrm{IgG}$ clearance in calves. J Virol. 1988;62:2234-7.https://doi.org/10.1128/jvi.62.7.2234-2237.1988

37. Urie NJ, Lombard JE, Shivley CB, Kopral CA, Adams AE, Earleywine TJ, et al. Preweaned heifer management on US dairy operations: part V. Factors associated with morbidity and mortality in preweaned dairy heifer calves. J Dairy Sci. 2018;101:9229-44. https://doi.org/10.3168/ jds.2017-14019

38. Arthington JD, Jaynes CA, Tyler HD, Kapil S, Quigley JD III. The use of bovine serum protein as an oral support therapy following coronavirus challenge in calves.J Dairy Sci. 2002;85:1249- 
54. https://doi.org/10.3168/jds.S0022-0302(02)74189-1

39. Berge ACB, Besser TE, Moore DA, Sischo WM. Evaluation of the effects of oral colostrum supplementation during the first fourteen days on the health and performance of preweaned calves.J Dairy Sci. 2009;92:286-95. https://doi.org/10.3168/jds.2008-1433

40. Blum JW, Baumrucker CR. Insulin-like growth factors (IGFs), IGF binding proteins, and other endocrine factors in milk: role in the newborn. Adv Exp Med Biol. 2008;606:397-422. https://doi.org/10.1007/978-0-387-74087-4_16

41. Nissen A, Andersen PH, Bendixen E, Ingvartsen KL, Røntved CM. Colostrum and milk protein rankings and ratios of importance to neonatal calf health using a proteomics approach. J Dairy Sci. 2017;100:2711-28. https://doi.org/10.3168/jds.2016-11722 